\title{
Analyzing Information Dynamics within Trading Companies: Evidence from Indian Market
}

\author{
Shraddha Mishra1, Dilip Kumar² \\ ${ }^{1}$ IILM Institute for Higher Education, Lodhi Road, New Delhi, India \\ ${ }^{2}$ Indian Institute of Management, Kashipur, India \\ Email: shraddhamishra29@gmail.com
}

How to cite this paper: Mishra, S. and Kumar, D. (2018) Analyzing Information Dynamics within Trading Companies: Evidence from Indian Market. Theoretical Economics Letters, 8, 1279-1311. https://doi.org/10.4236/tel.2018.86084

Received: March 7, 2018

Accepted: April 27, 2018

Published: April 30, 2018

Copyright (c) 2018 by authors and Scientific Research Publishing Inc. This work is licensed under the Creative Commons Attribution International License (CC BY 4.0).

http://creativecommons.org/licenses/by/4.0/

\section{(c) () Open Access}

\begin{abstract}
The motive of the research is to assess the practices adopted by investors to counter total risk and profit with the criteria for the investment decision and to know that if insider information is providing better returns from investments. The research is a cross-sectional study of descriptive nature. Moreover, it is a causal research because of various causative influences being studied among the variables. In our study, there are often deeper psychological considerations (such as; profit earning capacity, forecasting capabilities, risk bearing attitude and several others) that even the respondent (brokers) may not be aware of. The researcher has consulted 767 share brokers, investors, and transfer agents of the equity shares. After applying content analysis over the feedback provided by them, the study has originated a questionnaire based on their interviews. The 382 respondents filled the final constructed instruments, and further were analyzed with the help of the Confirmatory factor analysis (CFA) and Exploratory factor analysis (EFA) to measure the model. The model suggests that the insider information always depends upon the profit earning capacity, forecasting capabilities, risk bearing attitude and investment decisions. The results assimilated with the theory of efficient market hypothesis (Fama; 1965) which suggests that no investor will be able to beat the market with either public or private information if the market is in the strong form of efficient. The outcome complied after the survey did propose the same concept that insider information very soon converts into the public information.
\end{abstract}

\section{Keywords}

Psychological Biases, Behavioural Finance, Financial Investment Decision Behavior, Exploratory Study, Qualitative Research 


\section{Introduction}

The soaring competition in the share market has been one of the most difficult challenges in the trading of the shares. Narrow margins and escalating pressure to provide better returns are the consequences of the high level of competition in the market. It leads to increasing costs, reduced customer loyalty, and low occupancy rate.

The increasing expectation of brokers or investors has changed the face of the market as they want superior returns from their investments. To meet these needs, investors are inclined to form investment strategies. Therefore, the challenge of maintaining long-term returns and high profit arises in the dynamic environment of the share market.

Investors come to financial markets with different motives for making investment decision concerning their funds. Investors find out new-fangled information from the previous one, and it becomes tricky for peoples to construct a good decision for long-term saving [1]. The attitude and behaviors of the investors determine their upcoming investment decision [2]. Investment decision will always depend upon the perception and behavior of investors to the concerned market condition. The environment of the market may also affect the investment choice [3].

According to Shapira and Venezia [4], there are two types of investors: individual investors and professional investors. Supporters of expected utility theory persevere that the behaviors of the individual investors are not as much relevant as compared to professional's investors [5]. If we isolate the investors as per their knowledge, then a very small group are found to be highly knowledgeable about its investments. Nevertheless, other groups of investors emerge to have less knowledge about the different investment strategies. The investor's behavior and traits are frequently involved in their financial decision, and they directly affect the investment decision of investors. The finance scholars like Rhodes [6], Carhart [7], Brown and Goetzman [8], Fama [9] concluded that past information would never be necessary to predict the future return on the investment. Annamaria, Lusardi, \& Olivia Mitchell [10] highlighted that share investor had made the financial errors and bad financial decision around the global crisis in 2008. The scarcity of financial literacy is the most imperative causes for poor financial decision making. Gallery, Natalie, Newton, and Cameron [11] suggest that financial knowledge and financial literacy affect the investment decision. People with the less financial literacy and have less ability to make a better financial decision, particularly about retirement planning [12]. The financial knowledge and forecasting is a vital factor in financial decision-making [13]. The risk is also the most imperative factor for investment decisions. In the modern world, the risk is considered as instinctive and intuitive which can be subdivided into two (i.e. perceived and acted upon). Slovic and Peters [14] intended that risk analysis brings logic, reason, and scientific deliberation for risk assessment and financial decision making. 
The motive of the research is to assess the practices adopted by investors to counter total risk and profit with the criteria for the investment decision and to know that if insider information is providing better returns from investments. It may also justify that if Indian stock market is in the strong form of efficiency or not. The relationship among investment decisions and insider information of brokers for Indian region is a new dimension and is still unexplored. Hence to bridge this research gap, the existing theoretical background has been studied to bring the novelty in the research. The scale in research is devised after related review of the literature as well as exploratory investigations trailed by series of validation analysis. On the basis of the decision revealed during the exploratory investigations a new dimension has been added in the original studies of Behavioural finance. The present research can be seen as the study incorporating both perception as well as functional attributes of investment professionals. We enquired about their market experiences, expectations, investor's sophistication and behavioural biases if any they have at the point of trading. However, many of the respondents were taciturn on the topic of critical issues related with market regulators and issues that are facing by them in the industry.

The study is divided into eight parts. The first part introduces the background and rationale of the study. The second portion explores the theoretical issues along with the review of the existing literature. Available literature has been reviewed into five strands (i.e. investment decision; risk-bearing attitude; forecasting capabilities; insider information and profit earning capacity). Third section talks about the procedure and sample. Data analysis and methodology of the study is covered under the fourth section of the study. Fifth section provides the discussion and summary of the results. Implication, limitations and future recommendations of the study is covered under section six and seven simultaneously. Finally, in last section conclusion is discussed in detail.

\section{Theoretical Background}

In the $21^{\text {st }}$-century investor decisions are often biased due to individual human behavior. Financial information, knowledge and forecasting are always considered as the main terminology for making essential investment decisions. In preceding literature, an extraordinary amount of researches have been conducted in the area of financial literacy [15] [16] [17]. In earlier studies it has been revealed that there is a direct and accurate relationship between investment decisions and financial literacy and it is also affected by age, gender, education, and experience [18] [19] [20]. Various researches have defined financial literacy, but the common definition is the ability to forecast the effective decisions made about the execution of financial resources or money [21] Hence, we have considered the forecast as the variable instead of literacy because literacy itself becomes a wide term to capture in studies.

\subsection{Empirical Literature on Investment Decision}

Financial knowledge influences the relationships between investment decisions 
and offers a base for safety [16]. It has been reported in studies that a person with more experience will have more knowledge than a person with less experience and these experience might be regarding age or investment [22]. Thus while making huge investment decisions, it is necessary to have financial knowledge.

There is line difference between financial knowledge and financial literacy. Financial knowledge means to know about finances or money and its values or having information about finances and money while financial literacy means that along with the knowledge about finances and having skills and abilities to utilize money or finances [23] [24] [25]. Investors sometimes feel confused and have problems in stock markets investment as they don't have the basic knowledge about the market which makes it difficult for them to invest. Christelis et al. [26] and McArdle et al. [27] explained that more wealth leads to investing more in the market and has better chances of attaining profitability but chances of better returns multiply because of highly valued financial knowledge about the markets. Ameriks et al. [28], Lusardi and Mitchell [20] also supported the relationship between the financial knowledge, financial literacy and investment decisions.

\subsection{Empirical Literature on Risk-Bearing Attitude}

Risk perception can be defined "the perceived damage or loss from the future" but according to Douglas "Risk will entail the probability of an event combined with the magnitude of the losses and gains". Individual perception of risk has an apparent relationship with investment decisions. Chance or gambling, financial investing, business related decisions, and a personal decision determines which decisions need to be taken by respondents. It will also show the degree of risk taking capacity [29] [30]. Personal decisions about financial investment are not determined by the familiarity and controllability on the market, but it is affected by the amount risk perceived by the investor [31].

Diacon \& Ennew [23], Warneryd [24], Jordan \& Kaas [25] suggested that people have different perceptions about the risk and return. It depends upon the prior information, responses and knowledge with them. Diacon \& Hasseldine [32] revealed that risk is an important factor that determines the results of investment decision and it further depends upon the category of knowledge that an investor possesses about the investment.

Recent studies have publicized that intuitive risk measures such as risk perception can be a better proxy for the intuition of investors about financial risks than can be variance and standard deviation [33] [34]. Rettinger and Hastie [35], Weber et al. [36] and Baucells and Rata [37] illustrated that differences in risk taking capacity over various content domain. These can be the financial domain (e.g. investment decision) or the health domain (e.g. seat-belt usage), and further, it can be explained by differences in risk perceptions. More precisely, these studies show that risk perceptions vary substantially for different content domains. 


\subsection{Empirical Literature on Forecasting Capabilities}

The prediction of error forecast can be possible only if the share analyst has the Information at the time of issue of quarterly earnings. For example, past earnings revelations [38] and past returns of the market [39] have a significant and positive correlation with forecast error. Any Firms financial characteristics such as dividend payment ratios, book-to-market ratios [40] [41], and book-tax differences [42] and accruals (Bradshaw et al., 2006) [43], may also predict forecast errors. Forecasts sometimes also under-weight the information received from the consensus forecast [44]. The prior literature documents an instance in which analysts forecast outputs can calculate forecast error. The predicted sign of analyst's revision with regards to the recent quarter's earnings forecast has the positive correlation with revised forecast error [45] [46]. Researchers suggested that biases may also occur in longer-horizon forecasts. The forecasts made by an analyst for longer than one-quarter horizons are optimistic; this may further lead to the earnings realization on the forecast date [47] [48]. Brav and Lehavy 2003 [49] documented that share price target revisions usually have a large window for announcement returns. The further suggested that forecast regarding appreciation of share prices often contains some information about future returns and may also contain significant bias. Bradshaw et al. [50] revealed that analysts do not exhibit continual ability to forecast the share price appreciation. Lim [51], $\mathrm{Ke}$ and $\mathrm{Yu}$ [48] have argued that analyst forecasts become optimistic at long-horizon and the pessimistic at short-horizon because of incentives receipt in favor with management. However, Jackson [52], Beyer and Guttman [53], Groysberg et al. [54] suggested that reason for optimism in share forecast is because of the encouragement to trade. On the other hand, Lin and McNichols, [55] argued the reason is to win investment banking business line. Researchers have also linked that the reason for under-weighting of analysts' forecasts is the information incentives [44] [56].

Since the innovation of first event study, numerous papers have demonstrated that premature identification of new information in the market can offer substantial profits. Inside traders by privileged information can consequently make excess returns by violating the assumption of the strong form of the market efficiency. Even the earliest research by Cowles [57] [58], make it clear that investment professionals do not bang the market returns. Until the 1960s, there was confirmation on the performance of security analysts, that there was a relative gap in knowledge about the share returns achieved by portfolio managers. Treynor [59] and Sharpe [60] had developed the capital asset pricing model and make it clear that the CAPM can provide a benchmark or better returns for performance analysis.

The detailed analysis of one hundred and fifteen mutual funds for the period 1955-64 by Jensen [61] to judge the performance of fund managers' finds that any extra advantage that portfolio manager earns is consumed by fees and expenses. Jensen concludes that "on usual, the fund's managers apparently were 
not much successful in their trading activities."

The Nobel laureate of 2013 "Fama" summarizes several subsequent studies of mutual fund and performance of institutional portfolio managers. Though few mutual fund managers have achieved trivial abnormal gross returns calculated before expenses, pension funds had underperformed the passive benchmarks by risk-adjusted returns. It is essential to note that efficient markets hypothesis doesn't rule out for small abnormal returns, earned before fees and expenses. Analysts might therefore still have a motivation to acquire and act on received valuable information from the market, though investors would not expect to receive more than average returns.

Grossman and Stiglitz [62] formalize the idea mentioned above, with a more sensible model of equilibrium that it must put down some incentive for security analysis. They suggested that concept of market efficiency have to acknowledge the few possibility of market inefficiencies. The evidence gathered during the decade of the 1960s and 1970s appeared to be largely consistent with their view. Although it was clear that markets could not be utterly efficient in the strong form of efficiency, there was prominent support for the weak and semi-strong forms. Even the studies were done only on a single version of strong form efficiency that centers just on the performance of the investment managers.

\subsection{Empirical literature on Insider Information}

A plethora of academic literature explores the reasons for the outperformance of insider traders and exclusively insider buying. According to a study done in Wharton School entitled "Estimating the returns to insider trading"; about one-fourth of the abnormal returns added within the initial five days after the trade and the rest half of abnormal returns accrue within the first month. The study had taken an all-inclusive sample of insider transactions made over the period of 22 years from 1975 to 1996. Jeng, Andrew Metrick, Richard Zeckhauser [63] estimated the returns gained by insiders when they trade with their own company's stock. The study constructed a rolling "purchase portfolio" that consist of all shares acquired by insiders for a six-month period and a parallel "sale portfolio" that consist of all shares which are sold by insiders for six months. The six-month period was chosen to correspond with "short-swing" rule of the Securities and Exchange Act, 1934. This rule prohibits profit-taking capacity by insiders for counterbalancing the trades done within six months.

The study employed performance-evaluation methods to scrutinize the returns gained by the purchase and sale portfolios. This method capitulates a proxy for value-weighted returns gained by the insider transactions. The proxy will be weighed up at the beginning of the execution day of trade. The research had tried to avoid the statistical hitches that plague event studies for the long-term returns. New methods were designed to guesstimate the returns gained by insiders. The study is different from the previous literature of insider-trading, which were focused on "level of informativeness" of insider. Using a wide-ranging sample of all reported insider transactions starting from 1975 to 
1996, they find that the purchase portfolio of insiders earns abnormal returns of additional 50 basis points per month. However, the sale portfolio is not able to earn abnormal returns. About one-fourth of the abnormal returns added within the initial five days after the trade and rest half of abnormal returns were accrued within the first month. The study focuses on portfolio-based approach and further allows for clear-cut decompositions of the performance of insiders signifies various characteristics. They further concluded that the abnormal returns in small firms are insignificantly different from large firms, and usually, the top executives didn't earn higher abnormal returns as compared to other insiders of the firms.

Finnerty [64] suggested that the strong-form of the efficient market hypothesis is always concerned with the reflection of all available public and private information in a security's price. In expressions of market participants, it states that no participants have higher expected profit as compared to others just because of the monopolistic access to information he has. A test of strong-form is done just to determine average abnormal return received by insiders from their market transactions. To determine if the market is effective will engross determining how an insider earns fare relative as compared to the rest of market in general.

Jaffe [65] documented that commonly called insiders are corporate officers, large stockholders and board of directors; they habitually command extensive attention in the market's financial community. Investors are always interested in knowing the amount of special information that an insider possesses with him or her, and another area of interest is to know the profit they take home from such knowledge. The middle investors try to find out valuable information from the official summary of corporate or the transactions of insider trading; these are listed in the monthly report that summarizes the transactions of corporate officials. The conclusion comes that maximum of the trading rules is based on the available official information because the sample considered in the study shows the residuals are greater as compared to the transaction cost. L. Inmoo [66] collected the evidence of insider trading of all companies on Amex, NYSE, and Nasdaq during the 1975 to 1995 period. Results revealed that insider trading is common in more than half of the firms considered in the sample; there is the evidence of at least some insider activity in the period of study. However, usually the insider's trade put a very little impact on market movement and few conditions arrives when their trades are reported to Securities and Exchange Commission (the SEC). Insiders in a summative sense are contrarian investors. Conversely, they can predict market movements in a better way as compared to simple contrarian strategies. Further, it is added that insiders may be able to predict cross-sectional returns of the stocks. The results showed that purchases of insiders are more informative as compared to sales of insiders. Insiders have better ability to forecast returns of smaller firms than a larger one. Lorie and Victor Niederhoffer [67] documented that SEC requires that insiders keep them in- 
formed regarding transactions made in the common equity stock and other convertible securities of their respective companies. "Insiders" are defined by them as the directors, officers, and owners of ten or more percent of the common equity stock of the listed companies on the New York Stock Exchange and American Stock Exchange. The SEC is interested in trading of insiders because of the belief that insiders ought not to exploit their exceptional opportunities regarding the developments in their companies for personal profit motives through short-term trading. Finally, the study expounded that the role of the intermediaries are much important in the market and they are controlling a large volume of trading to derive profitable trade. Rozeff and Zaman [68] believed that it is not startling that corporate insiders can earn profits from trading their stocks. However, it is surprising that outsiders can also earn abnormal returns just by imitating the insider trades using available information in the monthly publically reports. Studies suggest that the anomalous returns are well explained by the price to book size and price-earnings ratio effects. Domineering over these factors may reduce outsider profits by half of the net returns. There are two percent transactions costs that make outsider profits either zero or negative. Overall measured insider profits are reduced by controlling the factors like size and price/earnings effects. Hence, insider profits are reserved for approximately 3 percent per annum after removing 2 percent fee for transactions costs. Seyhun. H. N [69] examines the ability of aggregate insider trading to predict future stock returns. The research question raised that if insider trading can be recognized to bring changes in business conditions or changes in fundamentals. Results suggest that both conditions contribute towards the predictive capability of an insider trading.

\subsection{Empirical Literature on Profit Earning Capacity}

Terrance [70] has revealed that disposition effect is influencing the market prices and had the greater financial significance for the individual investor. The study suggested that the individual's behavior exhibits the disposition effects and hence they acquire the profitable stocks at a much higher rate as compared to unprofitable stock held in the market. The prospect theory given by Kahneman and Tversky's [71] for investments is the extension of disposition effect. In prospect theory, if there are choices concerning two and three outcomes of lotteries, people perform just to maximize the "S"-shaped curve or value function. The value function is analogous to the standard utility function excluding that it has been defined on gains and losses relatively to the levels of wealth. The function reacts concave in the sphere of gains and convex for losses. It is steeper for losses as compared to gains, which involves that people are normally risk-averse. The value function is the reference point from we can measure the gains and losses. Usually the status quo is considered to the reference point; on the other hand, there are several situations in which gains and losses are usually coded as 
per the aspiration or expectation level that vary as per the status quo. "A person, who has not made peace with his losses is likely to accept gambles that would be unacceptable to him otherwise" [71]. Schlarbaum et al. [72] analyze the trading records of 2500 accounts at large retail brokerage unit for the period 1964 to 1970. They described the disposition effect by analyzing the rates of investor's realized gains and losses relative to available opportunities they have. Badrinath and Lewellen [73] analyzed the another data set provided by the same retail brokerage unit for 3000 retail accounts over the period 1971 to 1979. The data set suggest that the recent investment comes from the discount brokers. By exploration of the discount brokerage records found from the sample, it can be suggested that the retail broker has put an influence on trading patterns of the market. The study had looked for evidence of trading motivated by the tax and suggested that the ratio stocks sold for a loss as compared to those sold for a gain are rising as the year passes. The study further evident that the tax-motivated trading is one of the biggest reason for the stock investment. Constantinides [74] illustrated the case of U.S. federal taxes from January 1987 to December 1993 and suggested that if there is transaction cost involved in a transaction, then no peculiarity or difference can occur between the long-term or short-term and tax rates and in such cases the investors must gradually increase their tax-loss selling transactions. Dyl [75], Badrinath and Lewellen [73] and Lakonishok and Smidt [76] reported that investors sell more losing investments nearby the end of the financial year. Shefrin and Statman [77] recommended that investors prefer to sell their losers in the month of December as a tool of self-control measure. They suggested that investors are unwilling to sell investments for a loss but be acquainted with the tax benefits of doing it. The year end is the deadline for becoming conscious about these losses. Consequently each year, investors rearrange realizing losses till December whilst they involve themselves to sell losers earlier than the deadline passes away.

\subsection{Observations from Existing Literature}

Since 1965, the efficient market hypothesis is a topic where a plethora of studies has been undertaken. Many studies mainly justify the aspects of the semi-strong and weak form of the efficient market hypothesis. But to justify the strong form of market efficiency very few studies have been undertaken to give the validation for the insider trading in the Indian stock market. Further, the majority of studies have used quantitative approaches to justify the performance of fund managers and the share brokers, but very few studies have been conducted based on interviewees based on their decisions and their perception. Hence, to bridge this gap the research has formulated a questionnaire based on several interviews. Interviews are intended at gaining a perceptive understanding of how share brokers, financial analyst, investment advisers and equity dealers work within the market today. Interviewees are asked precisely several questions about their investing firms: the types of services offered to them, the number of profitable 
financial transactions made by them, knowledge requirements for them, technical skills available with financial professionals, existing compliance and supervisory functions, types, and forms of compensation or emoluments they are getting for investment. Interviewees were also asked about the types of disclosures they are having while their investment strategy formulation. Based on the existing literature the study has put together the hypothesis regarding knowing the statistically significant relationship among investment decision, profit earning capacity, insider information, forecasting capabilities and risk bearing attitude of the financial professionals.

\section{Procedure and Sample}

The research is a cross-sectional study with descriptive nature. Moreover, it is a casual research. The participants of this study were share Brokers, investors, and transfer agents (i.e. individuals and institutional investors). Data have been collected through a questionnaire by consulting 767 share Brokers, investors, and transfer agents, i.e., those dealing with the investment of the equity shares. After applying content analysis over the feedback provided by them, the study has originated a questionnaire based on their observations and suggestions. The data collection technique used in the study is Snowball Sampling because our study talks about sensitive topics, personal networks, rare traits, and social relationships [78]. We have collected data from North Indian states (i.e. Delhi, NCR (National Capital Region), Gurgaon, Varanasi and Lucknow).

\subsection{Sample Characteristics}

Initially, 472 questionnaires were distributed and 403 were received back. Out of these 21 questionnaires were incomplete and were omitted. Therefore 382 questionnaires were used for the study, representing a response rate of 85.38 percent. The names of respondents or organization's names were not mentioned anywhere in the questionnaire to guarantee privacy and confidentiality. In Indian Equity segment, there were 6840 registered Stock Brokers (as on date Mar, 2015). Hence we have taken the 5 percent of the population size [79] to calculate the sample size (i.e. 342) and oversampling of 12 percent of the sample size (i.e. 41) has been done to solve the issue of sampling non-respondents suggested by [80] [81] [82] [83]. Hence, the sample size of 382 is considered for study. Demographic characteristic of respondents along with the standard deviation is mentioned in Table 1. The sample consists of following characteristics:

\subsubsection{Education}

In the research, the educational qualification of the respondents has been divided into three parts (i.e. graduation; post graduation and professional degree). Among the respondents, 165 respondents are a post graduate with the highest percentage of 43.19. A second lot of respondents are with the professional degree comprises of 40.84 percent of entire sample size. The remaining 15.97 percent respondents are share brokers who are a graduate. 


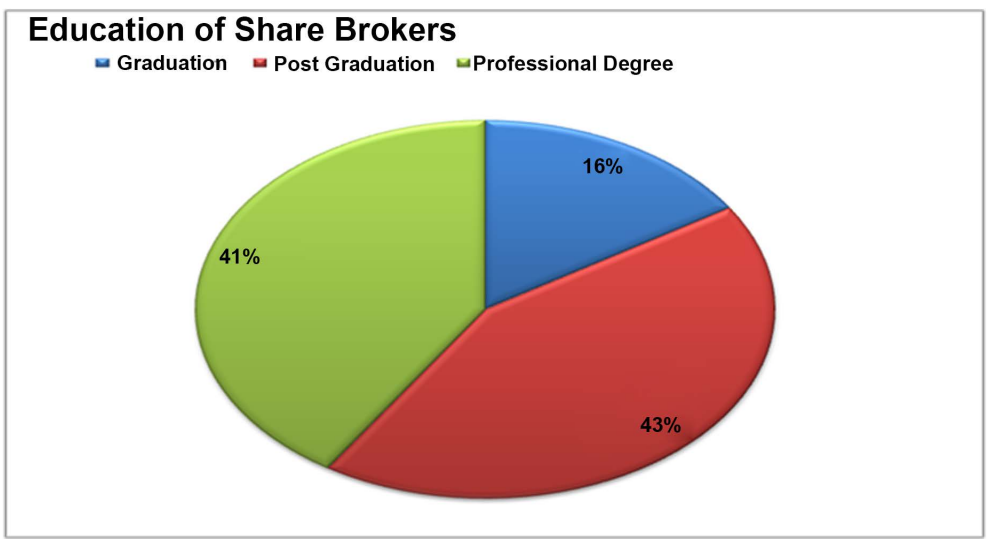

Table 1. Demographic characteristics of respondents.

\begin{tabular}{|c|c|c|c|c|c|}
\hline Trading Experience & Total & Percent & Median & Mean & St. Deviation \\
\hline More than 15 years & 32.00 & 8.38 & \multirow{5}{*}{105.00} & \multirow{5}{*}{76.40} & \multirow{5}{*}{54.68} \\
\hline 10 to 15 years & 4.00 & 1.05 & & & \\
\hline 5 to 10 years & 125.00 & 32.72 & & & \\
\hline 3 to 5 years & 105.00 & 27.49 & & & \\
\hline Less than 3 years & 116.00 & 30.37 & & & \\
\hline Kind of Stock & Total & Percent & Median & Mean & St. Deviation \\
\hline Large Caps & 47.00 & 12.30 & \multirow{4}{*}{68.00} & \multirow{4}{*}{95.50} & \multirow{4}{*}{98.31} \\
\hline Mid Caps & 235.00 & 61.52 & & & \\
\hline Small Caps & 89.00 & 23.30 & & & \\
\hline Unlisted Shares & 11.00 & 2.88 & & & \\
\hline Existing portfolio & Total & Percent & Median & Mean & St. Deviation \\
\hline 0 to 1 & 75.00 & 19.63 & \multirow{5}{*}{50.00} & \multirow{5}{*}{76.40} & \multirow{5}{*}{91.56} \\
\hline 2 to 5 & 233.00 & 60.99 & & & \\
\hline 6 to 10 & 50.00 & 13.09 & & & \\
\hline 11 to 30 & 15.00 & 3.93 & & & \\
\hline Above 30 & 9.00 & 2.36 & & & \\
\hline Education & Total & Percent & Median & Mean & St. Deviation \\
\hline Graduation & 61.00 & 15.97 & \multirow{3}{*}{156.00} & \multirow{3}{*}{127.33} & \multirow{3}{*}{57.62} \\
\hline Post Graduation & 165.00 & 43.19 & & & \\
\hline Professional Degree & 156.00 & 40.84 & & & \\
\hline
\end{tabular}

\subsubsection{Experience in Shares Trading}

The mean value for the sample regarding the total experience in trading the shares is 76.4. There were five heads under which the entire sample is distributed (i.e. more than 15 years; 10 to 15 years; 5 to 10 years; 3 to 5 years and Less than 3 years). Maximum of the respondents (i.e. 32.72 percent) came under the category of 5 to 10 years trading experience. Secondly, 27.49 percent of respondents 
were having 3 to 5 years of experience in share trading. The least percentage of participants are the investors of category 10 to 15 years. The experience of the trades signifies their age also. Hence we may infer that if the person is below the age of 35 - 40 years then he is less prone to bear the risk of the stock market the results assimilates with the results of Mehta and Aggarwal [84]. They suggest that the investors with the higher age prefer to invest more in saving bank accounts or post office as compared to other age groups.

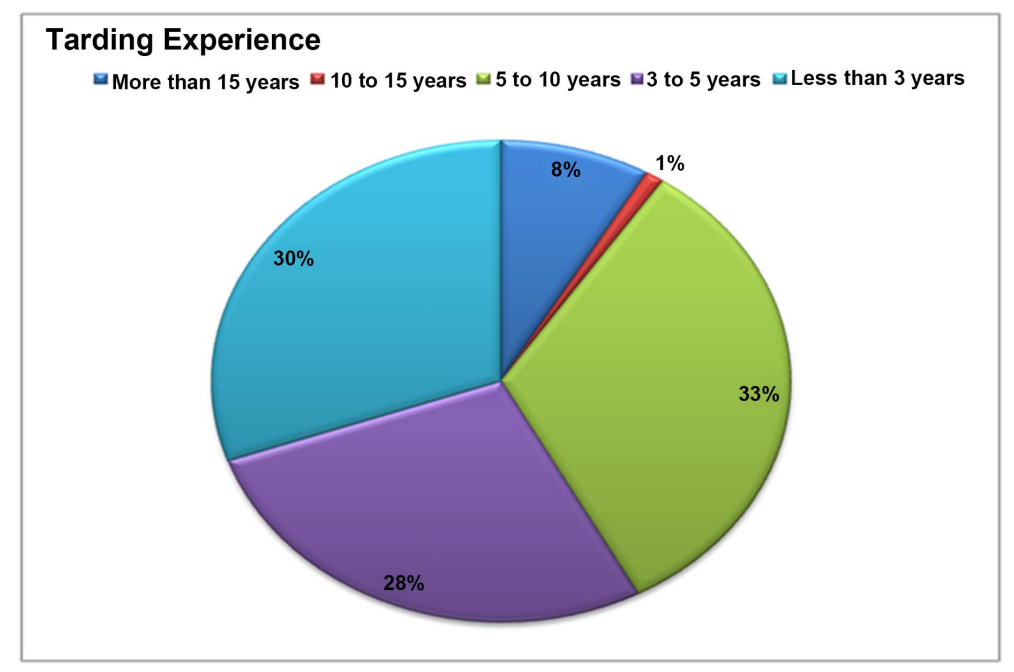

\subsubsection{Kind of Stock}

The study shows that in India people prefer to invest mostly in mid-cap shares as compared to Large and small Cap shares. The 61.52 percent of the respondents are in favor of investing in mid-Cap companies. However, just 2.88 percent are in favor of investing in unlisted shares. It shows that Indian stock market is investing in the organized sector more as compared to unlisted or unorganized shares.

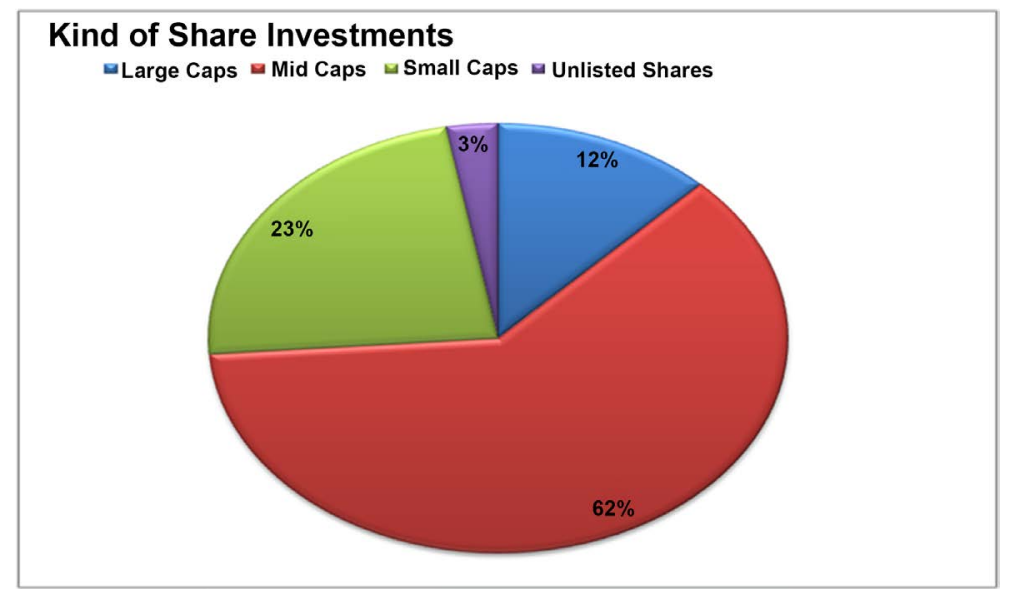

\subsubsection{Shares in Existing Portfolio}

The study suggests that the most of the share investors focus just on prime 2 to 5 shares. 233 respondents revealed that they emphasise basically on 2 to 5 shares 
in their portfolio. This signifies that to capture the volatility movement of 2 to 5 shares becomes easy of the investors. Just 2.36 percent of respondents show that they deal with more than 30 shares in their portfolio.

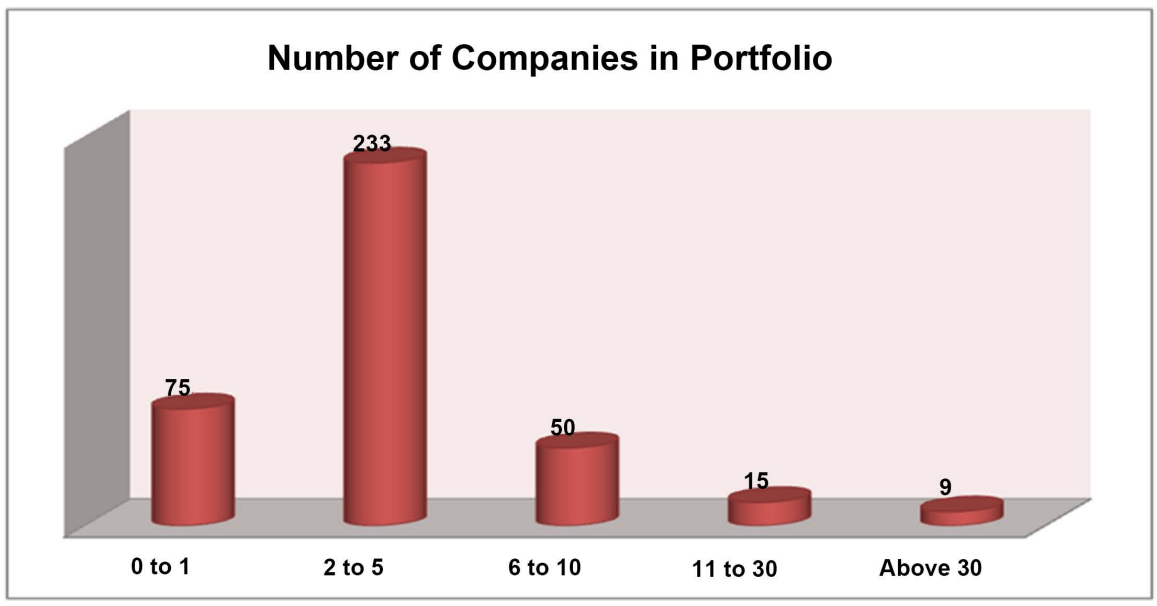

\subsection{Structural Equation Modelling (SEM)}

Multivariate analysis of variance represents the only single relationship between the dependent and independent variables. SEM can examine a series of dependence relationship simultaneously. It is particularly useful in testing theories that contain multiple equations involving dependence relationships. SEM is a family of statistical models that seek to explain the relationships among multiple variables. It examines the structure of interrelationships expressed in series of equation similar to a series of multiple regressions. SEM is based on two models, the measurement model that represents how measured variables come together to represent constructs and the structural model that shows how constructs are associated with each other.

Additionally, all the dimensions in our study have a Cronbach's $\alpha$ greater than 0.7 (our results reveals 89.4 percent of reliability), which complies with the criterion proposed by Nunnally [85] and Wortzel [86]. Factor analysis is taken as a tool to verify the convergent validity of the questionnaire. We extract factors with an eigen value greater than 1, a cumulative explained variation greater than 50 percent, and a factor loading greater than 0.5 [87]. It also has discriminant validity, because the correlation coefficient of each of the two factors is lower than the Cronbach's $\alpha$ of each dimension.

\subsection{Questionnaire Development}

Questionnaire development process can be summarised in five broad stages.

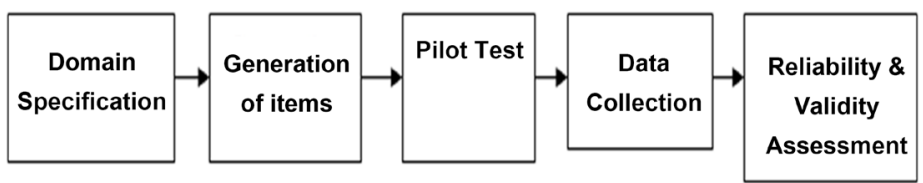


Domain specification includes definitions, identifying factors that define customer relationship management, identifying dependent variable.

Generation of items or variables were based on literature review after identifying factors that leads to fulfil the objective of the study.

Third phase of development of questionnaire was pilot testing. Academicians and practitioners were asked to judge the items pooled through literature review.

A pre-test was conducted with 50 respondents to check the reliability of the questionnaire.

Reliability has been measured by the coefficient of alpha gained by Cronbach, 1951. The alpha term measures the internal consistency and reveals that it should be more than 0.7 [85]. However, for this study it was found .894 (i.e. shown in Table 2).

\section{Data Analysis}

In the study we have considered five different antecedents and the following questions have been extracted after implementing the exploratory factor analysis. The five constructs or antecedents considered in the study are; Investment decision, profit earning capacity, insider information, forecasting capabilities and risk bearing attitude of the financial professionals. The variables that are considered in the research are shown in Table 3. However, the excluded factors from the analysis are mentioned in Table 4.

These variables are excluded due to the low factor loading or the cross loading issue. The exploratory factor analysis has shown that there must be five constructs that must be formulated in order to explain the nature of the total variance of the study. The extraction method used in the study is principal component analysis. This is a most widely acceptable method of the factor analysis. The cumulative extraction sums of squared loadings has shown as approx 70 percent of the total variance explained (i.e. refer to Table 5).

The Varimax with Kaiser Normalization Rotation method with maximum 6 iterations has been compiled in Table 6. Table 6 signifies the five factors as the construct with the variable to be considered in it. The results are based on these five constructs and based on these, initial set of 32 items has been developed. The constructs were measured on anchored 5-point Likert scale ranging from "Strongly agree" to "Strongly disagree" where 1 signifies strongly agree and 5 signifies strongly disagree always for positive items and vice-versa. Hair et al. [88] suggested that the item with less than 0.5 values must be removed. The

Table 2. KMO and Bartlett's test.

\begin{tabular}{lcc}
\hline \multicolumn{2}{l}{ Kaiser-Meyer-Olkin Measure of Sampling Adequacy. } & 0.894 \\
\hline & Approx. Chi-Square & 11946.353 \\
Bartlett's Test of Sphericity & df & 496 \\
& Sig. & 0.000 \\
\hline
\end{tabular}


study shows that proposed questionnaire has explained the total variance up to 70 percent; it also reveals the appropriateness of data [89].

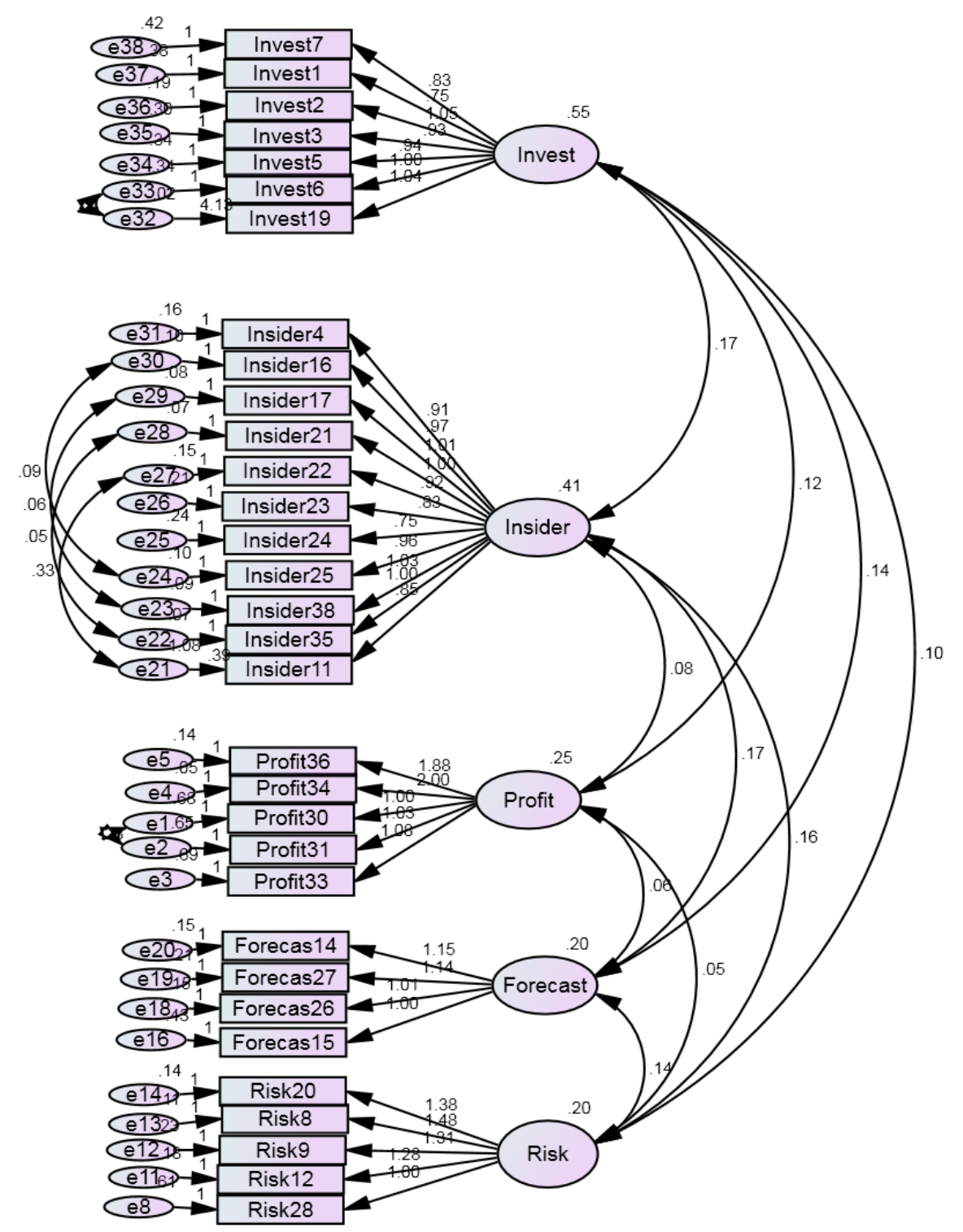

\subsection{Path Diagram}

For the establishment of the relationship among the variables, we have formulated the aforesaid path diagram. The diagram signifies that there is a relationship among the variables considered in the study. The initial framework considered for the study is shown in Figure 1.

The path diagram created in the study and the initial conceptual framework are somewhat interlinked. The standardized regression weights gained by the study are mentioned in Table 7, Tables 14-18. The estimates range from 97 percent to 54 percent.

The weights of regression are found statistically significant at 5 percent level of significance. The unstandardized regression weight along with the construct 
Table 3. Statements Considered for the research.

If it is losing money, I know the burn rate.

Forecast

I know how much my investment will be diluted as a result of the founders getting an interest for their sweat equity.

Forecast

I know that adequate and reliable portfolio management services are available for individual investors.

Forecast

I buy shares based on technical forecast.

Forecast

I buy shares based on the company's fundamentals

Forecast

I have discussed this project with other current and potential investors.

Insider

I know that which project involves development of a new product, process or other technical innovation, I have independent confirmation that it will work or not.

I think the founders have invested an appropriate amount of cash in the project.

I know the board of directors sometimes.

Insider

I know and trust the people who are managing the organization.

I know what and how the promoters are being paid (if anything).

Insider

I know the history of the key implementers of the business plan.

I know the terms of employment, contractual and salary agreements for the key personnel.

I know the reputations of the current shareholders, officers and directors and key professionals to the project.

I prefer investing in familiar companies.

I know the internal aspects of companies and the credible third parties.

I have listed and defined my personal objectives for the investment.

I know my probable return on investment (ROI)

I know the payback period for the investment.

I know how long this opportunity has been available.

Insider

Insider

Insider

Insider

Insider

Insider

Insider

Invest

Invest

Invest

Invest

I understand the financial plan and believe the assumptions and projections are reasonable.

Invest

I know how and when I will get my capital back.

Invest

I could be legally bound to put up more money in the future.

Invest

I am interested in short term gains from my investment in shares.

Profit

I Invest in shares mainly for long term capital gains.

Profit

I booked abnormal returns many time during my trading history

Profit

I am an active investor who trades every hour and make profit generally in every week.

Profit

I book profits after I reach the desired goals.

Profit

If I am purchasing equity, I know what I am purchasing (common shares, preferred shares)

\section{Risk}

I know if there are warrants or share options attached. Risk

I know how much I could lose and the risk of loss on the investment. Risk

In my investment instrument all the regulatory requirements

(Environmental, zoning, patent searches, etc.) have been met.

Risk 


\section{Continued}

I know where the raised funds will be used.

I know if some or all of my investment is secured by assets.

I understand the significance of the structure on my current and future risks.

Risk

Indian company managements are now taking more care of the shareholders interest.

Risk

I prefer investing in new upcoming companies with good prospects.

Risk

I hold certain shares for a very long time for sentimental reasons.

Risk

Table 4. List of excluded variables from questionnaire.

\begin{tabular}{cc}
\hline I know how much I could lose and the risk of loss on the investment. & Risk10 \\
\hline I know where the raised funds will be used. & Risk13 \\
I know if some or all of my investment is secured by assets. & Risk18 \\
I prefer investing in new upcoming companies with good prospects. & Risk29 \\
I hold certain shares for a very long time for sentimental reasons. & Risk32 \\
I buy shares based on the company's fundamentals & Forecast37 \\
\hline
\end{tabular}

Table 5. Extracted factors, eigenvalue, percentage and cumulative percentage of variance explained.

\begin{tabular}{cccc}
\hline Factor & Eigenvalue & Percentage of Variance explained & $\begin{array}{c}\text { Cumulative percentage of } \\
\text { variance explained }\end{array}$ \\
\hline 1 & 12.212 & 38.164 & 38.164 \\
2 & 4.055 & 12.673 & 50.837 \\
3 & 2.626 & 8.208 & 59.045 \\
4 & 2.376 & 7.426 & 66.471 \\
5 & 1.111 & 3.472 & 69.943 \\
\hline
\end{tabular}

reliability (denoted by C.R.) and standard error (denoted by S.E.) is mentioned in the Table 8. The below table shows that p-value is significant for all the variables considered in the study. This highlights the presence of strong positive relationship among the variables and hence these confirmed construct are taken in the study.

Results also signify that the variables undertaken in the study are significantly correlated. Moreover, the covariances of the Group number 1 and the Default model is also found to be statistically significant. The corresponding results are reported in Table 9 and Table 10.

\subsection{Confirmatory Factor Analysis}

Ahire, Golhar and Waller [90] suggested that confirmatory factor analysis (CFA) always provides improved control for gauging unidimensionality (i.e., up to which extent the items related to a specific factor measures one single construct or antecedent) as compared to exploratory factor analysis (EFA). It is a more 
Table 6. Rotated component matrix ${ }^{\mathrm{a}}$.

\begin{tabular}{|c|c|c|c|c|c|c|}
\hline Codes & Items & Fact 1 & Fact 2 & Fact 3 & Fact 4 & Fact 5 \\
\hline Invest 1 & $\begin{array}{l}\text { I have listed and defined my } \\
\text { personal objectives for the } \\
\text { investment. }\end{array}$ & & 0.683 & & & \\
\hline Invest 2 & $\begin{array}{l}\text { I know my probable return on } \\
\text { investment (ROI) }\end{array}$ & & 0.843 & & & \\
\hline Invest 3 & $\begin{array}{l}\text { I know the payback period for the } \\
\text { investment. }\end{array}$ & & 0.789 & & & \\
\hline Invest 5 & $\begin{array}{l}\text { I know how long this opportunity } \\
\text { has been available. }\end{array}$ & & 0.743 & & & \\
\hline Invest 6 & $\begin{array}{l}\text { I understand the financial plan and } \\
\text { believe the assumptions and } \\
\text { projections are reasonable. }\end{array}$ & & 0.833 & & & \\
\hline Invest 19 & $\begin{array}{l}\text { I could be legally bound to put up } \\
\text { more money in the future. }\end{array}$ & & 0.861 & & & \\
\hline Invest 7 & $\begin{array}{l}\text { I know how and when I will get my } \\
\text { capital back. }\end{array}$ & & 0.701 & & & \\
\hline Insider 4 & $\begin{array}{l}\text { I have discussed this project with } \\
\text { other current and potential } \\
\text { investors. }\end{array}$ & 0.805 & & & & \\
\hline Insider 16 & $\begin{array}{l}\text { I think the founders have invested } \\
\text { an appropriate amount of cash in } \\
\text { the project. }\end{array}$ & 0.842 & & & & \\
\hline Insider 17 & $\begin{array}{l}\text { I know the board of directors, and } \\
\text { entitled to represent sometimes. }\end{array}$ & 0.882 & & & & \\
\hline Insider 21 & $\begin{array}{l}\text { I know and trust the people who are } \\
\text { managing the organization. }\end{array}$ & 0.895 & & & & \\
\hline Insider 22 & $\begin{array}{l}\text { I know what and how the promoters } \\
\text { are being paid (if anything). }\end{array}$ & 0.858 & & & & \\
\hline Insider 23 & $\begin{array}{l}\text { I know the history of the key } \\
\text { implementers of the business plan. }\end{array}$ & 0.753 & & & & \\
\hline Insider 24 & $\begin{array}{l}\text { I know the terms of employment, } \\
\text { contractual and salary agreements } \\
\text { for the key personnel. }\end{array}$ & 0.709 & & & & \\
\hline Insider 25 & $\begin{array}{l}\text { I know the reputations of the } \\
\text { current shareholders, officers and } \\
\text { directors and key professionals to } \\
\text { the project. }\end{array}$ & 0.852 & & & & \\
\hline Insider 38 & $\begin{array}{l}\text { I know the internal aspects of } \\
\text { companies and the credible third } \\
\text { parties. }\end{array}$ & 0.872 & & & & \\
\hline Insider 35 & $\begin{array}{l}\text { I prefer investing in familiar } \\
\text { companies. }\end{array}$ & 0.899 & & & & \\
\hline Insider 11 & $\begin{array}{l}\text { I know that which project involves } \\
\text { development of a new product, } \\
\text { process or other technical } \\
\text { innovation, I have independent } \\
\text { confirmation that it will work or } \\
\text { not. }\end{array}$ & 0.828 & & & & \\
\hline Forecas 14 & $\begin{array}{l}\text { If it is losing money, I know the } \\
\text { burn rate. }\end{array}$ & & & & & 0.736 \\
\hline
\end{tabular}




\section{Continued}

\begin{tabular}{|c|c|c|c|c|}
\hline Forecas 27 & $\begin{array}{l}\text { I buy shares based on technical } \\
\text { forecast. }\end{array}$ & & & 0.707 \\
\hline Forecas 26 & $\begin{array}{l}\text { I know that adequate and reliable } \\
\text { portfolio management services are } \\
\text { available for individual investors. }\end{array}$ & & & 0.711 \\
\hline Forecas 15 & $\begin{array}{l}\text { I know how much my investment } \\
\text { will be diluted as a result of the } \\
\text { founders getting an interest for their } \\
\text { sweat equity. }\end{array}$ & & & 0.52 \\
\hline Risk 20 & $\begin{array}{l}\text { I understand the significance of the } \\
\text { structure on my current and future } \\
\text { risks. }\end{array}$ & 0.766 & & \\
\hline Risk 8 & $\begin{array}{l}\text { If I am purchasing equity, I know } \\
\text { what I am purchasing (common } \\
\text { shares, preferred shares) }\end{array}$ & 0.813 & & \\
\hline Risk 9 & $\begin{array}{l}\text { I know if there are warrants or share } \\
\text { options attached. }\end{array}$ & 0.793 & & \\
\hline Risk 12 & $\begin{array}{l}\text { In my investment instrument all the } \\
\text { regulatory requirements } \\
\text { (Environmental, zoning, patent } \\
\text { searches, etc.) have been met. }\end{array}$ & 0.762 & & \\
\hline Risk 28 & $\begin{array}{l}\text { Indian company managements are } \\
\text { now taking more care of the } \\
\text { shareholders interest }\end{array}$ & 0.571 & & \\
\hline Profit 30 & $\begin{array}{l}\text { I am interested in short term gains } \\
\text { from my investment in shares. }\end{array}$ & & 0.735 & \\
\hline Profit 31 & $\begin{array}{l}\text { I Invest in shares mainly for long } \\
\text { term capital gains. }\end{array}$ & & 0.736 & \\
\hline Profit 33 & $\begin{array}{l}\text { I booked abnormal returns many } \\
\text { time during my trading history }\end{array}$ & & 0.716 & \\
\hline Profit 34 & $\begin{array}{l}\text { I am an active investor who trades } \\
\text { every hour and make profit } \\
\text { generally in every week. }\end{array}$ & & 0.855 & \\
\hline Profit 36 & $\begin{array}{l}\text { I book profits after I reach the } \\
\text { desired goals. }\end{array}$ & & 0.84 & \\
\hline
\end{tabular}

Extraction Method: Principal Component Analysis. Rotation Method: Varimax with Kaiser Normalization. a. Rotation converged in 6 iterations.

systematic process of construct's overall reliability and validation. Hence in the study, we have applied the CFA and EFA. Leary-Kelly and Vokurka [91] suggested that convergent validity signifies that multiple methods for measuring the data set will provide the same results ever. Construct validity involves the estimation of the operationalization of the target variables considered in the study. Further, it had been suggested that Unidimensionality, reliability, convergent validity and discriminant validity are the way to prove the measures of Construct validity. Byrne revealed that if comparative fit index (CFI) must be 0.90 or above then it is evident that there is unidimensionality in data. Hence, this scale also supports the study of Byrne [92]. Ahire, Golhar and Waller [90] presented in their study that if the reliability and unidimensionality exist in scale then further validation analysis will strengthen the results. These tests for the goodness 
Table 7. Standardized regression weights.

\begin{tabular}{|c|c|c|c|}
\hline \multicolumn{3}{|c|}{ Standardized regression weights } & \multirow{2}{*}{$\begin{array}{c}\text { Estimate } \\
0.788\end{array}$} \\
\hline Invest 6 & $<---$ & Invest & \\
\hline Invest 5 & $<---$ & Invest & 0.766 \\
\hline Invest 3 & $<---$ & Invest & 0.781 \\
\hline Invest 2 & $<---$ & Invest & 0.870 \\
\hline Invest 1 & $<---$ & Invest & 0.671 \\
\hline Insider 25 & $<---$ & Insider & 0.892 \\
\hline Insider 24 & $<---$ & Insider & 0.699 \\
\hline Insider 23 & $<---$ & Insider & 0.758 \\
\hline Insider 22 & $<---$ & Insider & 0.836 \\
\hline Insider 21 & $<---$ & Insider & 0.927 \\
\hline Insider 17 & $<---$ & Insider & 0.914 \\
\hline Insider 16 & $<---$ & Insider & 0.890 \\
\hline Insider 4 & $<---$ & Insider & 0.820 \\
\hline Forecas 15 & $<---$ & Forecast & 0.567 \\
\hline Forecas 26 & $<---$ & Forecast & 0.760 \\
\hline Forecas 27 & $<---$ & Forecast & 0.747 \\
\hline Forecas 14 & $<---$ & Forecast & 0.801 \\
\hline Risk 28 & $<---$ & Risk & 0.499 \\
\hline Risk 12 & $<---$ & Risk & 0.800 \\
\hline Risk 9 & $<---$ & Risk & 0.772 \\
\hline Risk 8 & $<---$ & Risk & 0.894 \\
\hline Risk 20 & $<---$ & Risk & 0.853 \\
\hline Profit 30 & $<---$ & Profit & 0.520 \\
\hline Profit 31 & $<---$ & Profit & 0.542 \\
\hline Profit 33 & $<---$ & Profit & 0.548 \\
\hline Profit 34 & $<---$ & Profit & 0.979 \\
\hline Profit 36 & $<---$ & Profit & 0.930 \\
\hline Invest 19 & $<---$ & Invest & 0.815 \\
\hline Invest 7 & $<---$ & Invest & 0.688 \\
\hline Invest 19 & $<---$ & e32 & 0.580 \\
\hline Insider 11 & $<---$ & $\mathrm{e} 21$ & 0.596 \\
\hline Insider 11 & $<---$ & Insider & 0.803 \\
\hline Insider 35 & $<---$ & Insider & 0.927 \\
\hline Insider 38 & $<---$ & Insider & 0.909 \\
\hline
\end{tabular}


Table 8. Regression weights.

\begin{tabular}{|c|c|c|c|c|c|c|}
\hline \multicolumn{3}{|c|}{ Regression Weights } & \multirow{2}{*}{$\begin{array}{c}\text { Estimate } \\
1.000\end{array}$} & \multirow[t]{2}{*}{ S.E. } & \multirow[t]{2}{*}{ C.R. } & \multirow[t]{2}{*}{$\mathbf{P}$} \\
\hline Invest 6 & $<---$ & Invest & & & & \\
\hline Invest 5 & $<---$ & Invest & 0.940 & 0.059 & 15.904 & $* * *$ \\
\hline Invest 3 & $<---$ & Invest & 0.930 & 0.057 & 16.309 & $* * *$ \\
\hline Invest 2 & $<---$ & Invest & 1.045 & 0.056 & 18.584 & $* * *$ \\
\hline Invest 1 & $<---$ & Invest & 0.749 & 0.055 & 13.569 & $* * *$ \\
\hline Insider 25 & $<---$ & Insider & 0.965 & 0.033 & 29.068 & $* * *$ \\
\hline Insider 24 & $<---$ & Insider & 0.750 & 0.043 & 17.319 & $* * *$ \\
\hline Insider 23 & $<---$ & Insider & 0.825 & 0.041 & 19.999 & $* * *$ \\
\hline Insider 22 & $<---$ & Insider & 0.917 & 0.037 & 24.556 & $* * *$ \\
\hline Insider 21 & $<---$ & Insider & 0.997 & 0.014 & 72.044 & $* * *$ \\
\hline Insider 17 & $<---$ & Insider & 1.012 & 0.032 & 31.153 & $* * *$ \\
\hline Insider 16 & $<---$ & Insider & 0.972 & 0.034 & 28.808 & $* * *$ \\
\hline Insider 4 & $<---$ & Insider & 0.905 & 0.039 & 23.475 & $* * *$ \\
\hline Forecas 15 & $<---$ & Forecast & 1.000 & & & \\
\hline Forecas 26 & $<---$ & Forecast & 1.014 & 0.097 & 10.481 & $* * *$ \\
\hline Forecas 27 & $<---$ & Forecast & 1.141 & 0.110 & 10.386 & $* * *$ \\
\hline Forecas 14 & $<---$ & Forecast & 1.146 & 0.106 & 10.761 & $* * *$ \\
\hline Risk 28 & $<---$ & Risk & 1.000 & & & \\
\hline Risk 12 & $<---$ & Risk & 1.278 & 0.130 & 9.830 & $* * *$ \\
\hline Risk 9 & $<---$ & Risk & 1.313 & 0.136 & 9.681 & $* * *$ \\
\hline Risk 8 & $<---$ & Risk & 1.475 & 0.144 & 10.257 & $* * *$ \\
\hline Risk 20 & $<---$ & Risk & 1.380 & 0.137 & 10.088 & $* * *$ \\
\hline Profit 30 & $<---$ & Profit & 1.000 & & & \\
\hline Profit 31 & $<---$ & Profit & 1.033 & 0.093 & 11.082 & $* * *$ \\
\hline Profit 33 & $<---$ & Profit & 1.076 & 0.126 & 8.561 & $* * *$ \\
\hline Profit 34 & $<---$ & Profit & 1.997 & 0.175 & 11.389 & $* * *$ \\
\hline Profit 36 & $<---$ & Profit & 1.876 & 0.165 & 11.351 & $* * *$ \\
\hline Invest 19 & $<---$ & Invest & 1.043 & 0.042 & 24.731 & $* * *$ \\
\hline Invest 7 & $<---$ & Invest & 0.830 & 0.059 & 13.989 & $* * *$ \\
\hline Invest 19 & $<---$ & e32 & 4.132 & & & \\
\hline Insider 11 & $<---$ & e21 & 0.389 & & & \\
\hline Insider 11 & $<---$ & Insider & 0.847 & 0.038 & 22.414 & $* * *$ \\
\hline Insider 35 & $<---$ & Insider & 1.000 & & & \\
\hline Insider 38 & $<---$ & Insider & 1.025 & 0.033 & 30.709 & $* * *$ \\
\hline
\end{tabular}

fit of model mentioned in Table 11 and validation analysis is given in Table 12 respectively. Hu and Bentler [93] and Hair et al. [88] have given the thresholds listed in the figure given: 


\begin{tabular}{|l|l|}
\hline Measure & Threshold \\
\hline Chi-square/df $(\mathrm{cmin} / \mathrm{df})$ & $<\mathbf{3}$ good; $<5$ sometimes permissible \\
\hline p-value for the model & $>0.05$ \\
\hline CFI & $>0.95$ great; $>0.90$ traditional; $>0.80$ sometimes permissible \\
\hline GFI & $>0.95$ \\
\hline AGFI & $>0.80$ \\
\hline SRMR & $<0.09$ \\
\hline RMSEA & $<0.05$ good; $0.05-0.10$ moderate; $>0.10$ bad \\
\hline PCLOSE & $>0.05$ \\
\hline
\end{tabular}

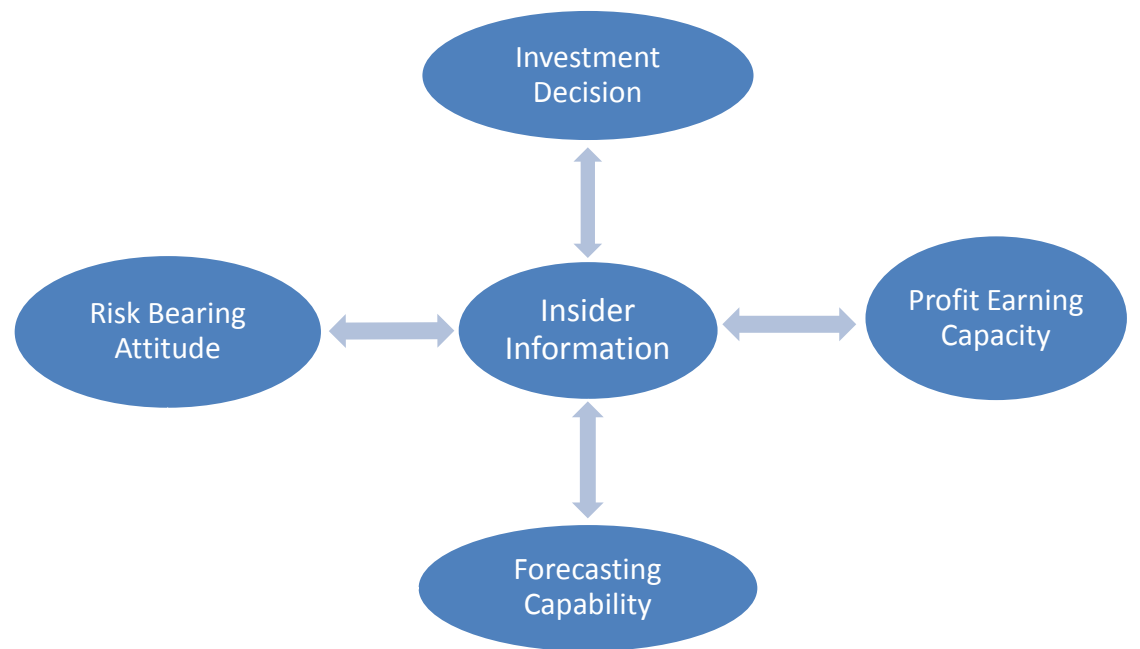

Figure 1. Conceptual model for Indian brokers.

Table 9. Covariances.

\begin{tabular}{ccccccc}
\hline & Covariances & & Estimate & S.E. & C.R. & P \\
\hline Invest & $<->$ & Profit & 0.125 & 0.024 & 5.099 & $* * *$ \\
Risk & $<-->$ & Profit & 0.052 & 0.014 & 3.685 & $* * *$ \\
Forecast & $<->$ & Profit & 0.061 & 0.015 & 4.039 & $* * *$ \\
Insider & $<->$ & Profit & 0.083 & 0.019 & 4.322 & $* * *$ \\
Invest & $<->$ & Insider & 0.173 & 0.029 & 6.050 & $* * *$ \\
Invest & $<->$ & Forecast & 0.142 & 0.024 & 5.833 & $* * *$ \\
Invest & $<->$ & Risk & 0.097 & 0.022 & 4.484 & $* * *$ \\
Insider & $<->$ & Risk & 0.158 & 0.023 & 6.843 & $* * *$ \\
Insider & $<->$ & Forecast & 0.168 & 0.023 & 7.301 & $* * *$ \\
Forecast & $<->$ & Risk & 0.140 & 0.022 & 6.429 & $* * *$ \\
\hline
\end{tabular}

\subsection{Robustness Testing}

Further, in order to determine the comparative importance of the five construct considered in the study regression analysis might become an effective tool. 
Table 10. Correlations.

\begin{tabular}{cccc}
\hline Correlations & & & Estimate \\
\hline Invest & $<->$ & Profit & 0.333 \\
Risk & $<->$ & Profit & 0.232 \\
Forecast & $<->$ & Profit & 0.269 \\
Insider & $<-->$ & Profit & 0.256 \\
Invest & $<-->$ & Insider & 0.363 \\
Invest & $<->$ & Forecast & 0.425 \\
Invest & $<->$ & Risk & 0.292 \\
Insider & $<->$ & Risk & 0.549 \\
Insider & $<->$ & Forecast & 0.581 \\
Forecast & $<->$ & Risk & 0.698 \\
\hline
\end{tabular}

Table 11. Convergent validity.

\begin{tabular}{ccc}
\hline Measures of Model Fit & Default Model Summary & Threshold \\
CMIN/DF & 2.483 & $<3$ \\
P-value for model & 0.000 & $>0.05$ \\
CFI & 0.944 & $>0.95$ \\
GFI & 0.847 & $>0.95$ \\
AGFI & 0.819 & $>0.80$ \\
SRMR & 0.034 & $<0.09$ \\
RMSEA & 0.062 & $<0.05$ \\
PCLOSE & 0.000 & $>0.05$ \\
\hline
\end{tabular}

Table 12. Validation analysis.

\begin{tabular}{cccccccccc}
\hline & CR & AVE & MSV & ASV & Forecast & Invest & Profit & Insider & Risk \\
\hline Forecast & 0.813 & 0.525 & 0.487 & 0.269 & 0.724 & & & & \\
Invest & 0.911 & 0.595 & 0.181 & 0.127 & 0.425 & 0.771 & & & \\
Profit & 0.843 & 0.538 & 0.111 & 0.076 & 0.269 & 0.333 & 0.733 & & \\
Insider & 0.967 & 0.732 & 0.338 & 0.209 & 0.581 & 0.363 & 0.256 & 0.855 & \\
Risk & 0.880 & 0.602 & 0.487 & 0.232 & 0.698 & 0.292 & 0.232 & 0.549 & 0.776
\end{tabular}

No validity concerns-wahoo!

Hence to do the robustness testing we have considered the insider information as the dependent variable and rest all constructs as independent. Unstandardized Beta $(\beta)$ coefficient provides the relative importance of the independent variable towards the dependent. The variable with the largest coefficient value represents the most important in terms of its influence on insider information and vice 
versa. The results for ordinary least square regression are mentioned in Table 13. The F statistics is found to be 49.488 and overall model is significant with 5 percent level of confidence. The percentage of variance in overall model explained by the independent variable studied together is 58.7 percent. All the factors in the study were found to be significant and stay on in the equation for explaining insider information of financial professionals. The results revealed that insider information is much revealed with the help of the forecasting capability a financial professional carries with him/her. The factor considered in the study refers that insider information altogether dependent upon the investment, forecasting, risk-bearing and profit earning capacity of an investor.

\section{Discussion and Summary}

The existing literature pretends that investment decisions are affected by education, gender, age and experience [15] [16] [18] [19]. Our results also indicate that investment decision is an integral factor [23] [24] [25]. The study is first of its kind of study done in the area of behavioural finance to know that insider information of investment professionals depend upon how many factors. The results are developed through the reliable and valid instrument for assessing insider Information of investment professional in Indian market. The scale in research is devised after related review of the literature as well as exploratory investigations trailed by series of validation analysis. On the basis of the decision revealed during the exploratory investigations a new dimension has been added in the original studies of Behavioural finance. The present research can be seen as the study incorporating both perception as well as functional attributes of investment professionals. The clear thought has been evolved from the research is that the insider information always depend upon the profit earning capacity, Forecasting capabilities, risk bearing attitude and investment decisions. This

Table 13. Ordinary linear regression analysis.

\begin{tabular}{|c|c|c|c|c|c|c|}
\hline \multirow[t]{2}{*}{ Regression Model } & \multicolumn{2}{|c|}{$\begin{array}{l}\text { Unstandardized } \\
\text { Coefficients }\end{array}$} & \multirow[t]{2}{*}{$\mathbf{t}$} & \multirow[t]{2}{*}{ Sig. } & \multirow{2}{*}{$\begin{array}{c}\text { Order of } \\
\text { Importance } \\
\text { (as per B coefficient) }\end{array}$} & \multirow[t]{2}{*}{ F } \\
\hline & B & Std. Error & & & & \\
\hline (Constant) & 13.223 & 1.952 & 6.772 & 0.000 & Constant & \\
\hline Invest & 0.136 & 0.056 & 2.425 & 0.016 & 4 & \\
\hline forecast & 0.704 & 0.130 & 5.398 & 0.000 & 1 & $\begin{array}{l}49.488 \\
(0.000)\end{array}$ \\
\hline Risk & 0.440 & 0.110 & 4.013 & 0.000 & 2 & \\
\hline Profit & 0.167 & 0.069 & 2.433 & 0.015 & 3 & \\
\hline $\mathbf{R}$ & & & & 0.587 & & \\
\hline R SQUARE & & & & 0.344 & & \\
\hline Adj-R Square & & & & 0.337 & & \\
\hline St. Error & & & & 4.961 & & \\
\hline Durbin Watson & & & & 2.03 & & \\
\hline
\end{tabular}

Dependent Variable: Insider. 
Table 14. Factor-invest: standardized regression weights.

\begin{tabular}{cccc}
\hline Variable & & & Estimate \\
\hline Invest 6 & $<--$ & Invest & 0.788 \\
Invest 5 & $<--$ & Invest & 0.766 \\
Invest 3 & $<--$ & Invest & 0.781 \\
Invest 2 & $<--$ & Invest & 0.870 \\
Invest 1 & $<--$ & Invest & 0.671 \\
Invest 19 & $<--$ & Invest & 0.815 \\
Invest 7 & $<--$ & Invest & 0.688 \\
\hline
\end{tabular}

Goodness-of-fit measures shows a good model fit for factor. $(\chi 2=6.20 ; \mathrm{CMIN} / \mathrm{df}=1.240 ; \mathrm{CFI}=0.999$; $\mathrm{TLI}=0.997$; $\mathrm{RMSEA}=0.027$; AGFI $=0.965$ ).

Table 15. Factor-insider: standardized regression weights.

\begin{tabular}{cccc}
\hline Variables & & & Estimate \\
\hline Insider 25 & $<--$ & Insider & 0.892 \\
Insider 24 & $<--$ & Insider & 0.699 \\
Insider 23 & $<--$ & Insider & 0.758 \\
Insider 22 & $<--$ & Insider & 0.836 \\
Insider 21 & $<--$ & Insider & 0.927 \\
Insider 17 & $<--$ & Insider & 0.914 \\
Insider 16 & $<--$ & Insider & 0.890 \\
Insider 4 & $<--$ & Insider & 0.820 \\
Insider 11 & $<--$ & Insider & 0.803 \\
Insider 35 & $<--$ & Insider & 0.927 \\
Insider 38 & $<--$ & Insider & 0.909 \\
\hline
\end{tabular}

Goodness-of-fit measures shows a good model fit for factor $(\chi 2=20.474$; $\mathrm{CMIN} / \mathrm{df}=2.275 ; \mathrm{CFI}=0.989$; $\mathrm{TLI}=0.981 ; \mathrm{RMSEA}=0.063 ;$ AGFI $=0.915$ ).

Table 16. Factor-forecast: standardized regression weights.

\begin{tabular}{cclc}
\hline Variables & & & Estimate \\
\hline Forecas 15 & $<---$ & Forecast & 0.855 \\
Forecas 26 & $<--$ & Forecast & 0.805 \\
Forecas 27 & $<--$ & Forecast & 0.659 \\
Forecas 14 & $<---$ & Forecast & 0.859 \\
Forecas 15 & $<---$ & Forecast & 0.707 \\
\hline
\end{tabular}

Goodness-of-fit measures shows a good model fit for factor. $(\chi 2=13.432$; $\mathrm{CMIN} / \mathrm{df}=2.686$; $\mathrm{CFI}=0.990$; TLI $=0.971 ;$ RMSEA $=0.073 ;$ AGFI $=0.891$ ). 
Table 17. Factor-profit: standardized regression weights.

\begin{tabular}{cccc}
\hline Variables & & & Estimate \\
\hline Profit 30 & $<---$ & Profit & 0.796 \\
Profit 31 & $<---$ & Profit & 0.796 \\
Profit 33 & $<---$ & Profit & 0.854 \\
Profit 34 & $<---$ & Profit & 0.745 \\
Profit 36 & $<---$ & Profit & 0.803 \\
\hline
\end{tabular}

Goodness-of-fit measures shows a good model fit for factor. $(\chi 2=1.353$; CMIN $/ \mathrm{df}=0.676$; CFI $=1.00$; TLI $=1.00$; RMSEA $=0.001$; AGFI $=0.959$ ).

Table 18. Factor-risk: standardized regression weights.

\begin{tabular}{cccc}
\hline Variables & & & Estimate \\
\hline Risk 28 & $<---$ & Risk & 0.756 \\
Risk 12 & $<---$ & Risk & 0.831 \\
Risk 9 & $<---$ & Risk & 0.865 \\
Risk 8 & $<---$ & Risk & 0.801 \\
Risk 20 & $<---$ & Risk & 0.765 \\
\hline
\end{tabular}

Goodness-of-fit measures shows a good model fit for factor. $(\chi 2=6.821 ; \mathrm{CMIN} / \mathrm{df}=1.364 ; \mathrm{CFI}=0.998$; $\mathrm{TLI}=0.996 ; \mathrm{RMSEA}=0.034 ; \mathrm{AGFI}=0.973)$.

signifies that if the investor will just carry the insider information and no other proficiency than it will be tougher for them to beat the Indian stock market. The results assimilated with Mac Crimmon \& Wehrung [29] [30]; where they suggested that risk is main aspect in finance and it will always affect the investment decision and the profit of investor.

\section{Implications and Limitations}

The data and information used in the study will be very useful for investment managers and market regulators. The result gives an idea to fund manager about how to formulate investment decision, how much risk much be taken and how to generate a better portfolio for taking the privilege of investment opportunities for achieving better returns. The statements we make about how to invest can be applied from judging the future investment opportunities. Through this study, we may predict the insider information available with the investment professional on the basis of the four different variables mentioned in the research.

There are various variables which are either directly or indirectly linked with investment, so the retail investor may check for these efficiencies available with fund managers and also take decision in the light of these variables. Hence, the data will be useful for retail and professional investors, and fund managers who deliver the financial services and financial consultation in the equity market. We interviewed many certified and knowledgeable professionals of Indian market to 
gain a better understanding or perception of equity dealers and investment professional about their work and experience. Topics included in the interviews were about their opinions about the companies they are investing into, or the business practices of the firms and real market conditions with respect to the current regulatory structure. We also enquired about their market experiences, expectations, investor's sophistication and behavioural biases if any they have at the point of trading. However, many of the respondents were taciturn on the topic of critical issues related with market regulators and issues that are facing by them in the industry.

\section{Future Recommendation}

Future researchers may use age experience and gender as the moderator in the path analysis. The results may also be expanded if the economic outcomes may be taken into the consideration. Furthermore, human capital or the board of the director's perception may also perhaps be used as a mediator or as a moderator.

\section{Concluding Observations}

The motive of the research is to assess the practices adopted by investors to counter total risk and profit with the criteria for the investment decision and to know that if insider information is providing better returns from investments. This may also justify that if Indian stock market is in strong form of efficiency or not. The relationship among investment decisions and insider information of brokers for Indian region is a new dimension and still unexplored. Hence to bridge this research gap, the existing theoretical background has been studied to bring the novelty in the finance research.

The study itself does not evaluate the legal and regulatory framework, nor does this will provide recommendations on existing regulations and policies. To gain the insight that lies with the investment professionals with regards to the current business practices adopted by them. The main rationale of our study was to provide a factual background to Securities Exchange Board of India (SEBI) for its regulations and evaluations with reference to investment professionals and equity broker or dealers.

The study offers a description of the practices adopted by these professionals and also describes that how these investment professionals comprehend the information received by them about the firms they are investing into. The study is first of its kind of study done in the area of behavioural finance to know that insider information of investment professionals depends upon how many factors.

The fascinating results suggest that the insider information always depends upon the profit earning capacity, forecasting capabilities, risk bearing attitude and investment decisions. This signifies that if the investor will just carry the insider information and no other proficiency than it will be tougher for them to beat the Indian stock market. The results assimilate with theory of efficient market hypothesis [9] [94]; Brown and Goetzman [6] [7] [8] suggest that no in- 
vestor will be able to beat the market with either public or private information if the market is in the strong form of efficient. The outcome complied after the survey to propose the same concept that insider information very soon converts into the public information. Hence no one can retrieve the abnormal returns from the market and it may be concluded that Indian market lies in the strong form of market efficiency.

\section{References}

[1] Clark-Murphy, M. and Soutar, G.N. (2004) What Individual Investor's Value: Some Australian Evidence. Journal of Economic Psychology, 25, 539-555. https://doi.org/10.1016/S0167-4870(03)00056-4

[2] Masini, A. and Menichetti, E. (2010) Investment Decisions in the Renewable Energy Field: An Analysis of Main Determinants. Proceedings of Technology Management for Global Economic Growth (PICMET), Phuket, 18-22 July 2010, 1-11.

[3] Wiengarten, F., Pagell, M. and Fynes, B. (2012) Supply Chain Environmental Investments in Dynamic Industries: Comparing Investment and Performance Differences with Static Industries. International Journal of Production Economics, 135, 541-551. https://doi.org/10.1016/j.ijpe.2011.03.011

[4] Shapira, Z. and Venezia, I. (2001) Patterns of Behavior of Professionally Managed and Independent Investors. Journal of Banking \& Finance, 25, 1573-1587. https://doi.org/10.1016/S0378-4266(00)00139-4

[5] Cooper, R. and Ross, T.W. (1998) Bank Runs: Liquidity Costs and Investment Distortions. Journal of Monetary Economics, 41, 27-38. https://doi.org/10.1016/S0304-3932(97)00070-6

[6] Rhodes, J.S. (2000) Usability Can Save Your Company. Retrieved on October, 10, 2001.

[7] Carhart, M.M. (1997) On Persistence in Mutual Fund Performance. The Journal of Finance, 52, 57-82. https://doi.org/10.1111/j.1540-6261.1997.tb03808.x

[8] Brown, S.J. and Goetzmann, W.N. (1995) Performance Persistence. The Journal of Finance, 50, 679-698. https://doi.org/10.1111/j.1540-6261.1995.tb04800.x

[9] Malkiel, B.G. and Fama, E.F. (1970) Efficient Capital Markets: A Review of Theory and Empirical Work. The Journal of Finance, 25, 383-417. https://doi.org/10.1111/j.1540-6261.1970.tb00518.x

[10] Lusardi, A. and Mitchell, O.S. (2011) Financial Literacy and Planning: Implications for Retirement Wellbeing (No. w17078). National Bureau of Economic Research. https://doi.org/10.3386/w17078

[11] Irving, K., Gallery, G., Gallery, N. and Newton, C. (2011) "I Can't Get No Satisfaction”... Or Can I?: A Study of Satisfaction with Financial Planning and Client Well-Being. JASSA, 2, 36.

[12] Keene, M.A. and Peterson, D.R. (2007) The Importance of Liquidity as a Factor in Asset Pricing. Journal of Financial Research, 30, 91-109. https://doi.org/10.1111/j.1475-6803.2007.00204.x

[13] Fonseca, R., Mullen, K.J., Zamarro, G. and Zissimopoulos, J. (2012) What Explains the Gender Gap in Financial Literacy? The Role of Household Decision Making. Journal of Consumer Affairs, 46, 90-106. https://doi.org/10.1111/j.1745-6606.2011.01221.x

[14] Slovic, P. and Peters, E. (2006) Risk Perception and Affect. Current Directions Psy- 
chological Science, 15, 322-325.

https://doi.org/10.1111/j.1467-8721.2006.00461.x

[15] Lusardi, A. and Mitchell, O.S. (2007) Baby Boomer Retirement Security: The Roles of Planning, Financial Literacy, and Housing Wealth. Journal of Monetary Economics, 54, 205-224. https://doi.org/10.1016/j.jmoneco.2006.12.001

[16] Van Rooij, M.C., Kool, C.J. and Prast, H.M. (2007) Risk-Return Preferences in the Pension Domain: Are People Able to Choose? Journal of Public Economics, 91, 701-722. https://doi.org/10.1016/j.jpubeco.2006.08.003

[17] Fry, T.R., Mihajilo, S., Russell, R. and Brooks, R. (2008) The Factors Influencing Saving in a Matched Savings Program: Goals, Knowledge of Payment Instruments, and Other Behavior. Journal of Family and Economic Issues, 29, 234-250. https://doi.org/10.1007/s10834-008-9106-y

[18] Agnew, J.R. and Szykman, L.R. (2005) Asset Allocation and Information Overload: The Influence of Information Display, Asset Choice, and Investor Experience. The Journal of Behavioral Finance, 6, 57-70. https://doi.org/10.1207/s15427579jpfm0602_2

[19] Bailey, W., Li, H., Mao, C.X. and Zhong, R. (2003) Regulation Fair Disclosure and Earnings Information: Market, Analyst, and Corporate Responses. The Journal of Finance, 58, 2487-2514. https://doi.org/10.1046/j.1540-6261.2003.00613.x

[20] Lusardi, A. and Mitchell, O.S. (2007) Financial Literacy and Retirement Planning: New Evidence from the Rand American Life Panel. Michigan Retirement Research Center Research Paper No. WP, 157. https://doi.org/10.2139/ssrn.1095869

[21] Schagen, S. and Lines, A. (1996) Financial Literacy in Adult Life: A Report to the Natwest Group Charitable Trust. NFER, 36-45.

[22] Chen, H. and Volpe, R. P. (1998) An Analysis of Personal Financial Literacy among College Students. Financial Services Review, 7, 107-128. https://doi.org/10.1016/S1057-0810(99)80006-7

[23] Diacon, S. and Ennew, C. (2001) Consumer Perceptions of Financial Risk. The Geneva Papers on Risk and Insurance. Issues and Practice, 26, 389-409. https://doi.org/10.1111/1468-0440.00125

[24] Warneryd, K.E. (2001) Stock-Market Psychology. Books.

[25] Jordan, J. and Kaas, K.P. (2002) Advertising in the Mutual Fund Business: The Role of Judgmental Heuristics in Private Investors' Evaluation of Risk and Return. Journal of Financial Services Marketing, 7, 129-140. https://doi.org/10.1057/palgrave.fsm.4770079

[26] Christelis, D., Jappelli, T. and Padula, M. (2010) Cognitive Abilities and Portfolio Choice. European Economic Review, 54, 18-38. https://doi.org/10.1016/j.euroecorev.2009.04.001

[27] McArdle, J.J., Smith, J.P. and Willis, R. (2009) Cognition and Economic Outcomes in the Health and Retirement Survey (No. w15266). National Bureau of Economic Research. https://doi.org/10.3386/w15266

[28] Ameriks, J., Caplin, A. and Leahy, J. (2003) Wealth Accumulation and the Propensity To Plan. Quarterly Journal of Economics, 118, 1007-1047. https://doi.org/10.1162/00335530360698487

[29] MacCrimmon, K.R. and Wehrung, D.A. (1986) Assessing Risk Propensity. In: Recent Developments in the Foundations of Utility and Risk Theory, Springer Netherlands, 291-309. https://doi.org/10.1007/978-94-009-4616-3_19

[30] MacCrimmon, K.R. and Wehrung, D.A. (1990) Characteristics of Risk Taking Ex- 
ecutives. Management Science, 36, 422-435. https://doi.org/10.1287/mnsc.36.4.422

[31] Slovic, P., Fischhoff, B. and Lichtenstein, S. (1986) The Psychometric Study of Risk Perception. In: Risk Evaluation and Management, Springer US, 3-24. https://doi.org/10.1007/978-1-4613-2103-3_1

[32] Diacon, S. and Hasseldine, J. (2007) Framing Effects and Risk Perception: The Effect of Prior Performance Presentation Format on Investment Fund Choice. Journal of Economic Psychology, 28, 31-52. https://doi.org/10.1016/j.joep.2006.01.003

[33] Hertwig, R., Barron, G., Weber, E.U. and Erev, I. (2004) Decisions from Experience and the Effect of Rare Events in Risky Choice. Psychological Science, 15, 534-539. https://doi.org/10.1111/j.0956-7976.2004.00715.x

[34] Klos, A., Weber, E.U. and Weber, M. (2005) Investment Decisions and Time Horizon: Risk Perception and Risk Behavior in Repeated Gambles. Management Science, 51, 1777-1790. https://doi.org/10.1287/mnsc.1050.0429

[35] Rettinger, D.A. and Hastie, R. (2001) Content Effects on Decision Making. Organizational Behavior and Human Decision Processes, 85, 336-359.

https://doi.org/10.1006/obhd.2000.2948

[36] Weber, E.U., Blais, A.R. and Betz, N.E. (2002) A Domain-Specific Risk-Attitude Scale: Measuring Risk Perceptions and Risk Behaviors. Journal of Behavioral Decision Making, 15, 263-290. https://doi.org/10.1002/bdm.414

[37] Baucells, M. and Rata, C. (2006) A Survey Study of Factors Influencing Risk-Taking Behavior in Real-World Decisions under Uncertainty. Decision Analysis, 3, 163-176. https://doi.org/10.1287/deca.1060.0075

[38] Abarbanell, J.S. and Bernard, V.L. (1992) Tests of Analysts' Overreaction/Underreaction to Earnings Information as an Explanation for Anomalous Stock Price Behavior. The Journal of Finance, 47, 1181-1207. https://doi.org/10.1111/j.1540-6261.1992.tb04010.x

[39] Abarbanell, J.S. (1991) Do Analysts' Earnings Forecasts Incorporate Information in Prior Stock Price Changes? Journal of Accounting and Economics, 14, 147-165. https://doi.org/10.1016/0165-4101(91)90003-7

[40] Hughes, J., Liu, J. and Su, W. (2008) On the Relation between Predictable Market Returns and Predictable Analyst Forecast Errors. Review of Accounting Studies, 13, 266-291. https://doi.org/10.1007/s11142-007-9065-9

[41] So, E.C. (2013) A New Approach to Predicting Analyst Forecast Errors: Do Investors Overweight Analyst Forecasts? Journal of Financial Economics, 108, 615-640. https://doi.org/10.1016/j.jfineco.2013.02.002

[42] Weber, D.P. (2009) Do Analysts and Investors Fully Appreciate the Implications of Book-Tax Differences for Future Earnings? Contemporary Accounting Research, 26, 1175-1206. https://doi.org/10.1506/car.26.4.7

[43] Bradshaw, M.T., Richardson, S.A. and Sloan, R.G. (2006) The Relation between Corporate Financing Activities, Analysts' Forecasts and Stock Returns. Journal of Accounting and Economics, 42, 53-85. https://doi.org/10.1016/j.jacceco.2006.03.004

[44] Chen, Q. and Jiang, W. (2006) Analysts' Weighting of Private and Public Information. Review of Financial Studies, 19, 319-355. https://doi.org/10.1093/rfs/hhj007

[45] Shane, P. and Brous, P. (2001) Investor and (Value Line) Analyst Underreaction to Information about Future Earnings: The Corrective Role of Non-Earnings-Surprise Information. Journal of Accounting Research, 39, 387-404. https://doi.org/10.1111/1475-679X.00018

[46] Raedy, J.S., Shane, P. and Yang, Y. (2006) Horizon-Dependent Underreaction in 
Financial Analysts' Earnings Forecasts. Contemporary Accounting Research, 23, 291-322. https://doi.org/10.1506/F2MW-D22D-WNQQ-D034

[47] Richardson, S., Teoh, S.H. and Wysocki, P.D. (2004) The Walk-Down to Beatable Analyst Forecasts: The Role of Equity Issuance and Insider Trading Incentives. Contemporary Accounting Research, 21, 885-924. https://doi.org/10.1506/KHNW-PJYL-ADUB-0RP6

[48] Ke, B. and Yu, Y. (2006) The Effect of Issuing Biased Earnings Forecasts on Analysts' Access to Management and Survival. Journal of Accounting Research, 44, 965-999. https://doi.org/10.1111/j.1475-679X.2006.00221.x

[49] Brav, A. and Lehavy, R. (2003) An Empirical Analysis of Analysts' Target Prices: Short-Term Informativeness and Long-Term Dynamics. The Journal of Finance, 58, 1933-1968. https://doi.org/10.1111/1540-6261.00593

[50] Bradshaw, M.T., Brown, L.D. and Huang, K. (2013) Do Sell-Side Analysts Exhibit Differential Target Price Forecasting Ability? Review of Accounting Studies, 18, 930-955. https://doi.org/10.1007/s11142-012-9216-5

[51] Lim, C. and McAleer, M. (2001) Forecasting Tourist Arrivals. Annals of Tourism Research, 28, 965-977. https://doi.org/10.1016/S0160-7383(01)00006-8

[52] Jackson, A.R. (2005) Trade Generation, Reputation, and Sell-Side Analysts. The Journal of Finance, 60, 673-717. https://doi.org/10.1111/j.1540-6261.2005.00743.x

[53] Beyer, A. and Guttman, I. (2011) The Effect of Trading Volume on Analysts' Forecast Bias. The Accounting Review, 86, 451-481.

https://doi.org/10.2308/accr.00000030

[54] Groysberg, B., Healy, P.M. and Maber, D.A. (2011) What Drives Sell-Side Analyst Compensation at High-Status Investment Banks? Journal of Accounting Research, 49, 969-1000. https://doi.org/10.1111/j.1475-679X.2011.00417.x

[55] Lin, H.W. and McNichols, M.F. (1998) Underwriting Relationships, Analysts' Earnings Forecasts and Investment Recommendations. Journal of Accounting and Economics, 25, 101-127. https://doi.org/10.1016/S0165-4101(98)00016-0

[56] Clement, M.B. and Tse, S.Y. (2005) Financial Analyst Characteristics and Herding Behavior in Forecasting. The Journal of Finance, 60, 307-341. https://doi.org/10.1111/j.1540-6261.2005.00731.x

[57] Cowles 3rd, A. (1933) Can Stock Market Forecasters Forecast? Econometrica: Journal of the Econometric Society, 1, 309-324. https://doi.org/10.2307/1907042

[58] Cowles, A. (1944) Stock Market Forecasting. Econometrica: Journal of the Econometric Society, 12, 206-214. https://doi.org/10.2307/1905433

[59] Treynor, J.L. (1961) Toward a Theory of Market Value of Risky Assets. Unpublished Manuscript, 6.

[60] Sharpe, W.F. (1964) Capital Asset Prices: A Theory of Market Equilibrium under Conditions of Risk. The Journal of Finance, 19, 425-442.

[61] Jensen, M.C. (1968) The Performance of Mutual Funds in the Period 1945-1964. The Journal of Finance, 23, 389-416. https://doi.org/10.1111/j.1540-6261.1968.tb00815.x

[62] Grossman, S.J. and Stiglitz, J.E. (1980) On the Impossibility of Informationally Efficient Markets. The American Economic Review, 70, 393-408.

[63] Jeng, L.A., Metrick, A. and Zeckhauser, R. (1999) The Profits to Insider Trading: A Performance-Evaluation Perspective (No. w6913). National Bureau of Economic Research. https://doi.org/10.3386/w6913 
[64] Finnerty, J.E. (1974) Insiders' Activity and Inside Information: A Multivariate Analysis. Working Paper No. 98.

[65] Jaffe, J.F. (1974) Special Information and Insider Trading. The Journal of Business, 47, 410-428. https://doi.org/10.1086/295655

[66] Inmoo, L. (1997) Do Firms Knowingly Sell Overvalued Equity? Journal of Finance, 52, 1439-1466. https://doi.org/10.1111/j.1540-6261.1997.tb01116.x

[67] Lorie, J.H. and Niederhoffer, V. (1968) Predictive and Statistical Properties of Insider Trading. The Journal of Law and Economics, 11, 35. https://doi.org/10.1086/466642

[68] Rozeff, M.S. and Zaman, M.A. (1988) Market Efficiency and Insider Trading: New Evidence. Journal of Business, 61, 25-44. https://doi.org/10.1086/296418

[69] Seyhun, H.N. (1992) Effectiveness of the Insider-Trading Sanctions. The Journal of Law and Economics, 35, 149. https://doi.org/10.1086/467248

[70] Odean, T. (1998) Are Investors Reluctant to Realize Their Losses? The Journal of Finance, 53, 1775-1798. https://doi.org/10.1111/0022-1082.00072

[71] Kahneman, D. and Tversky, A. (1979) Prospect Theory: An Analysis of Decision under Risk. Econometrica: Journal of the Econometric Society, 47, 263-291. https://doi.org/10.2307/1914185

[72] Schlarbaum, G.G., Lewellen, W.G. and Lease, R.C. (1978) Realized Returns on Common Stock Investments: The Experience of Individual Investors. Journal of Business, 51, 299-325. https://doi.org/10.1086/295998

[73] Badrinath, S.G. and Lewellen, W.G. (1991) Evidence on Tax-Motivated Securities Trading Behavior. The Journal of Finance, 46, 369-382. https://doi.org/10.1111/j.1540-6261.1991.tb03755.x

[74] Constantinides, G.M. (1984) Optimal Stock Trading with Personal Taxes: Implications for Prices and the Abnormal January Returns. Journal of Financial Economics, 13, 65-89. https://doi.org/10.1016/0304-405X(84)90032-1

[75] Dyl, E.A. (1977) Capital Gains Taxation and Year-End Stock Market Behavior. The Journal of Finance, 32, 165-175. https://doi.org/10.1111/j.1540-6261.1977.tb03250.x

[76] Lakonishok, J. and Smidt, S. (1986) Volume for Winners and Losers: Taxation and Other Motives for Stock Trading. The Journal of Finance, 41, 951-974. https://doi.org/10.1111/j.1540-6261.1986.tb04559.x

[77] Shefrin, H. and Statman, M. (1985) The Disposition to Sell Winners Too Early and Ride Losers Too Long: Theory and Evidence. The Journal of Finance, 40, 777-790. https://doi.org/10.1111/j.1540-6261.1985.tb05002.x

[78] Kalpan, C.D., Korf, D. and Strek, C. (1987) Temporal and Social Contexts of Heroin-Using Populations: An Illustration of Snowball Sampling Technique. Journal of Nervous and Mental Disease, 175, 566-574. https://doi.org/10.1097/00005053-198709000-00009

[79] Cochran, W.G. (1977) Sampling Techniques. 3rd Edition, Wiley, Hoboken.

[80] Donald, M.N. (1967) Implications of Non-Response for the Interpretation of maiL Questionnaire Data. Public Opinion Quarterly, 24, 99-114. https://doi.org/10.1086/266934

[81] Hagbert, E.C. (1968) Validity of Questionnaire Data: Reported and Observed Attendance in an Adult Education Program. Public Opinion Quarterly, 25, 453-456.

[82] Johnson, P.O. (1959) Development of the Sample Survey as a Scientific Methodology. Journal of Experiential Education, 27, 167-176. 
https://doi.org/10.1080/00220973.1959.11010620

[83] Miller, L.E. and Smith, K.L. (1983) Handling Non Response Issues. Journal of EXtension, 21, 45-50.

[84] Mehta, S.K. and Aggarwal, N. (2011) The Effect of Demographics on Investment Choice: An Empirical Study of Investors in Jammu. Indian Journal of Finance, 5, 43-55.

[85] Nunnally, J.C. (1978) Psychometric Theory. McGraw-Hill Publ Co., New York.

[86] Wortzel, R. (1979) Multivariate Analysis. Prentice Hall, New Jersey. Zack, M. (1999) Developing a Knowledge Strategy. California Management Review, 41, 125-143.

[87] Kaiser, H.F. (1958) The Varimax Criterion for Analytic Rotation in Factor Analysis. Psychometrika, 23, 187-200. https://doi.org/10.1007/BF02289233

[88] Hair, J.F., Black, W.C., Babin, B.J., Anderson, R.E. and Tatham, R.L. (2010) Multivariate Data Analysis. 7th Edition, Pearson, New York.

[89] Stewart, D.W. (1981) The Application and Misapplication of Factor Analysis in Marketing Research. Journal of Marketing Research, 51-62. https://doi.org/10.2307/3151313

[90] Ahire, S.L., Golhar, D.Y. and Waller, M.A. (1996) Development and Validation of TQM Implementation Constructs. Decision Sciences, 27, 23-56. https://doi.org/10.1111/j.1540-5915.1996.tb00842.x

[91] O'Leary-Kelly, S.W. and Vokurka, R.J. (1998) The Empirical Assessment of Construct Validity. Journal of Operations Management, 16, 387-405. https://doi.org/10.1016/S0272-6963(98)00020-5

[92] Byrne, B.M. (1994) Structural Equation Modelling with EQS and EQS/Windows: Basic Concepts, Applications, and Programming. Sage.

[93] Hu, L.T. and Bentler, P.M. (1999) Cutoff Criteria for Fit Indexes in Covariance Structure Analysis: Conventional Criteria versus New Alternatives. Structural Equation Modeling, 6, 1-55. https://doi.org/10.1080/10705519909540118

[94] Fama, E.F. (1965) The Behavior of Stock-Market Prices. The Journal of Business, 38, 34-105. https://doi.org/10.1086/294743 